\title{
Fatty acid composition of underutilized corms, rhizomes and tubers
}

\author{
Tresina, P.S., Doss, A. and *Mohan, V.R. \\ Ethnopharmacology Unit, V.O.Chidambaram College, Thoothukudi - 628 008, Tamil Nadu, India
}

\begin{abstract}
Article history:
Received: 20 March 2020

Received in revised form: 23

April 2020

Accepted: 2 May 2020

Available Online: 13 May

2020
\end{abstract}

Keywords:

Fatty acid,

Palmitic acid,

Linoleic acid,

Xanthosoma sagittifolium

DOI:

https://doi.org/10.26656/fr.2017.4(5).123

\begin{abstract}
With escalating populace pressure and fast exhaustion of natural resources, it has become extremely vital to diversify the present time agriculture with the cultivation of some wild varieties of tubers, rhizomes and corms in order to meet various human nutrient needs. However, information regarding fatty acid composition is inadequate. The purpose of the present study was to examine the fatty acid composition of six samples of wild corms (Alocasia macrorrhiza, Amorphophallus paeoniifolius var. campanulata, A. sylvaticus, Colocasia esculenta, Xanthosoma sagittifolium, X. violaceum two species of rhizomes (Canna indica and Maranta arundinacea) and three species of tubers (Asparagus racemosus, Nymphaea pubescens and N. rubra) in order to assess the nutritional and biochemical significance. The total lipid was extracted from the corms, rhizomes and tubers using chloroform and methanol mixture in the ratio of 2:1 (w/v). Methyl esters were prepared from the lipids. Fatty acid analysis was performed by gas chromatography. Among the investigated species, corm of $X$. sagittifolium registered the highest amount of palmitic acid. Similarly, tubers of $A$. racemosus exhibited the highest amount of linoleic acid. The present investigation demonstrated that the corms, rhizomes and tubers act as a good source of fatty acid.
\end{abstract}

\section{Introduction}

India has one of the major concentrations of tribal population in the world. Forest plays a vital role in the economy as well as in the daily needs of the tribals. In times of resources when the staple food is in short supply, the tribals collect many types of wild roots and tubers to supplement their meagre food available at home (Vidyarthi, 1987). Roots and tubers refer to any growing plant that store edible material in the subterranean root, corm and tubers. The nutritional value of roots and tubers lies in their prospective ability to provide one of the best and cheapest sources of nutritional energy in the form of carbohydrates in expanding countries (Ugwu, 2009).

In India the cooked wild corms, rhizomes and tubers are known to be consumed by the Palliyar tribals living in Grizzled Giant Squirrel Wildlife Sanctuary, Srivilliputhur and Kanikkars living in the Agasthiarmalai Biosphere Reserve, Kanyakumari and Tirunelveli Districts, South-Eastern Slopes of Western Ghats, Tamil Nadu (Arinathan et al., 2007; Shanthakumari et al., 2008; Shajeela et al., 2011). Information regarding the chemical and nutritional content of wild edible corms, rhizomes and tubers are meagre (Babu et al., 1990; Nair and Nair, 1992; Rajalakshmi and Geervani, 1994; Bhandari et al., 2003; Udensi et al., 2008; Alozie et al., 2009; Arinathan et al., 2009; Mohan and Kalidass, 2010; Shajeela et al., 2013). Reports on fatty acid contents of other common varieties of yam and wild yam are available (Opute and Osagie, 1978; Kouassi et al., 1988; Muzac-Tucker et al., 1993; Alzoie et al., 2010; Shajeela et al., 2013). However, their fatty acids may be beneficial to human beings, since plant fatty acids have become a major player in the alleviation of most human diseases. For the first time in the present investigation, an attempt was made to understand the fatty acid composition of underutilized corms, rhizomes and tubers.

\section{Materials and methods}

\subsection{Plant sample}

Six samples of wild corms (Alocasia macrorrhiza Schott, Amorphophallus paeoniifolius (Dennst) Nicolson var. campanulata (Blume ex Decne) Sivadasam, $A$. sylvaticus (Roxb.) Kunth, Colocasia esculenta (L.) Schott, Xanthosoma sagittifolium (L) Schott $X$. 
violaceum Schott, two species of rhizomes (Canna indica L, Maranta arundinacea (L.) and three species of tubers (Asparagus racemosus Willd, Nymphaea pubescens Willd, and N. rubra Roxb ex Andrews) grown in sandy loam soil are consumed by the tribals Kanikkars/Palliyars were collected using multistage sampling technique in three consecutive rainy seasons during August and January 2016 from the South Eastern slopes of Western Ghats, Virudhunagar district, Kanyakumari district and Tirunelveli district, Tamil Nadu. The plant specimens were identified with the help of local flora and authenticated by Botanical Survey of India (Southern Circle) Coimbatore. The collected corms, rhizomes and tubers were weighed, peeled, cut into small pieces and dried at $40^{\circ} \mathrm{C}$ until the content weight was obtained. The dried samples were ground to a time powder by Willy mill. The powdered samples were stored in screw cap bottles at room temperature for further analysis.

\subsection{Lipid extraction and fatty acid analysis}

The total lipid was extracted from the corms, rhizomes and tubers according to the method of Folch et al. (1957) using chloroform and methanol mixture in the ratio of 2:1 (v/v). Methyl esters were prepared from the total lipids by the method of Metcalfe et al. (1966). Fatty acid analysis was performed by gas chromatography (ASHMACO, Japan; Model No: ABD20A) using an instrument equipped with a flame ionization detector and a glass column $(2 \mathrm{mx} 3 \mathrm{~mm})$ packed with $1 \%$ diethylene glycol succinate on chromosorb $\mathrm{W}$. The temperature conditions for $\mathrm{GC}$ were injector $200^{\circ} \mathrm{C}$ and detector $210^{\circ}$ C. The temperature of the oven was programmed from $180^{\circ} \mathrm{C}$ and the carrier gas was nitrogen at a flow rate of $30 \mathrm{ml} / \mathrm{min}$. Peaks were identified by comparison with authentic standards, quantified by peak area integration and expressed as the weight percentage of total methyl esters; the relative weight percentage of each fatty acid was determined from integrated peak areas.

\section{Results and discussion}

The results of crude fat content and fatty acid composition of wild corms Alocasia macrorrhiza, Amorphophallus paeoniifolius var. campanulata, A. sylvaticus, Colocasia esculenta, Xanthosoma sagittifolium $X$. violaceum, rhizomes Canna indica Maranta arundinacea and tubers Asparagus racemosus, Nymphaea pubescens and N. rubra are presented in Tables 1 and 2 . The data showed that the crude fat content of the wild corms, rhizomes and tubers ranged from $2.38 \%$ to $7.10 \%$. The fatty acid composition of underutilized corms, rhizomes and tubers ranged from $1.5 \%$ to $34.31 \%$. The results showed palmitic acid $(24.26$
$-31.57 \%)$, oleic acid (11.08 - 19.04\%) and linoleic acid $(28.36-34.31 \%)$ as the predominant fatty acid in the underutilized corms, rhizomes and tubers. The most abundant saturated fatty acid was palmitic acid. Similarly, the most abundant unsaturated fatty acid was linoleic acid. Among the species investigated, corms of Xanthosoma sagittifolium contained a high amount of palmitic acid (31.57\%). Similarly, tubers of Asparagus racemosus contained a higher amount of linoleic acid (34.31\%). All the investigated corms, rhizomes and tubers exhibited a higher level of unsaturated fatty acids. The polyunsaturated to saturated fatty acids $(\mathrm{P} / \mathrm{S})$ ratio varies in the range from 0.95 and 1.24.

The fatty acid composition of the various species of corms, rhizomes and tubers investigated in the present study was found to be in agreement with earlier reports in the tubers of Dioscorea alata (Ciacao and D’Appolonia, 1978); D. transversa (Brown et al., 1985); D. dumetorum varieties (Kouassi et al., 1988); D. tomentosa wild and edible (Alozie et al., 2010); Dioscorea spp. (Shajeela et al., 2011). Similarly, all the investigated corms, rhizomes and tubers contained more amount of unsaturated fatty acid linoleic. This is in consonance with an earlier report in the tubers of $D$. alata and D. kifida (Muzac-Tucker et al., 1993). The unsaturated ratio of the investigated corms, rhizomes and tubers is lower than the values reported earlier of $D$. alata (1:4), D. bulbifera (1:4), D. rotunda (1:8), D. cayenencis (1:8) (Opute and Osagie, 1978) and $D$. dumetorum (Alozie et al., 2010). Palmitic acid was the controlling saturated fatty acid, tracked by the unsaturated fatty acid, linoleic acid. Among the investigated corms, rhizomes and tubers, corms of Xanthosoma sagittifolium contained more amount of palmitic acid and tubers of Asparagus racemosus contained higher amount of linoleic acid when compared with other presently investigated species. Unsaturated fatty acids, particularly linolenic acid is required for normal functioning of the human body. The nutritional value of linoleic acid is due to its metabolism at tissue levels which produce hormone like prostaglandins. The ability of these prostaglandins includes lowering of blood pressure and construction of smooth muscle (Aurand et al., 1987). Linoleic and linolenic acids are the most important essential fatty acids required for growth, physiological functions and maintenance (Pugalenthi et al., 2004). The fatty acids composition and high amount of unsaturated fatty acids make corms, rhizomes and tubers suitable for nutritional applications. The presence of high levels of unsaturated fatty acids in all the presently investigated corms, rhizomes and tubers are nutritionally desirable. Plant fatty acids serve as good and healthy fat to the consumer and the low incidence of coronary heart disease (Alozie et al., 2009). The O/L 
Table 1. Fatty acid composition of underutilized corms

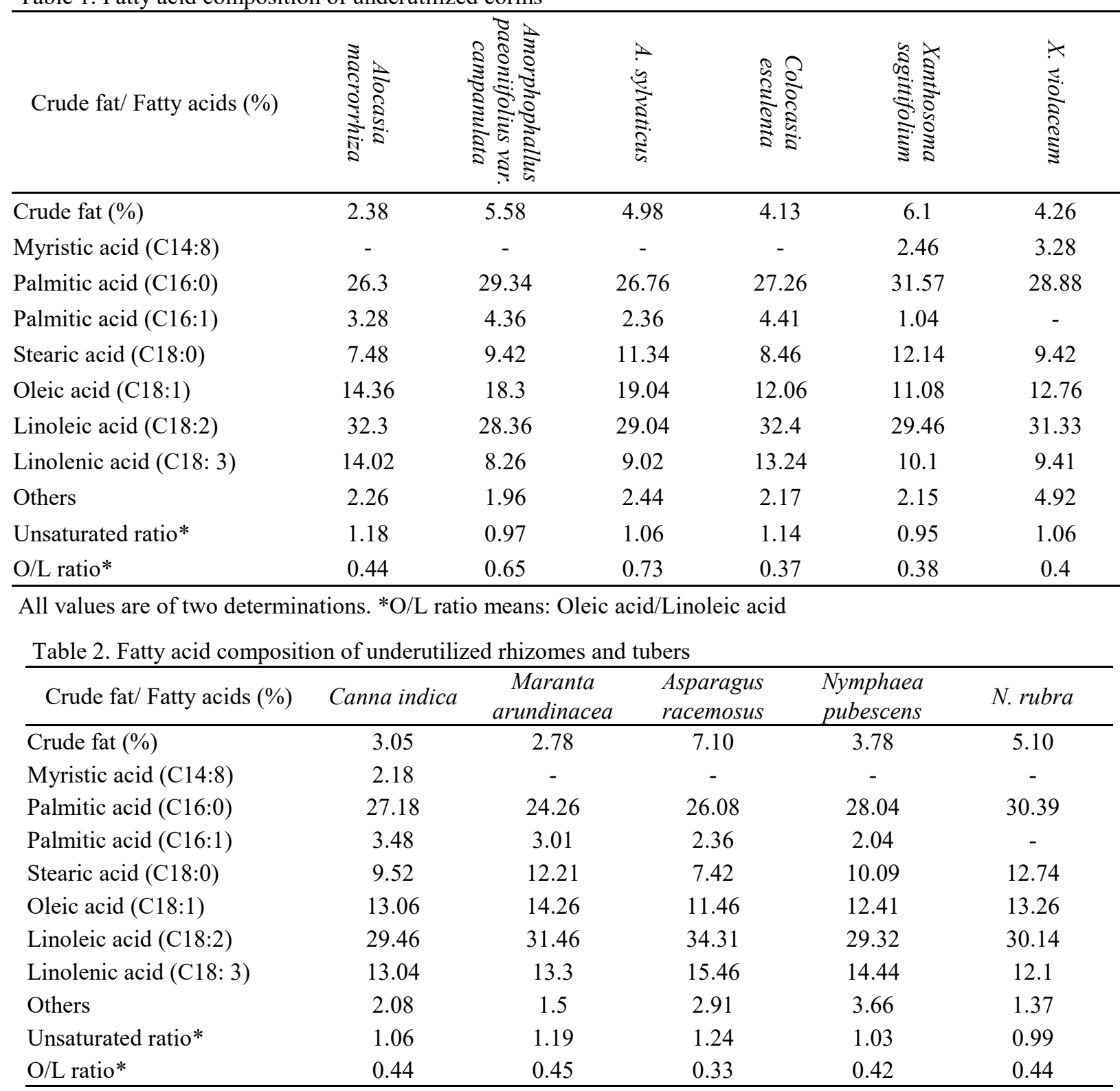

All values are of two determinations. *O/L ratio means: Oleic acid/Linoleic acid

ratio of lipids of presently investigated samples is lower in comparison with the average suggested earlier (Attia et al., 1996).

The role of fatty acid especially the polyunsaturated fatty acids (PUFAs) in the management of coronary heart disease can be considered as the function of fatty acid of plant origin. PUFAs is known to regulate prostaglandin synthesis, thus promoting wound healing activity that cannot be synthesized by man and must be obtained from the diet. It has been reported that dietary changes achieved greater reductions in cardiovascular risk factors and coronary heart disease mortality in a secondary prevention trial than any of the cholesterol-lowering studies to date. The consumption of corms, rhizomes and tubers will, therefore, supplement dietary fat with such essential fatty acids of linoleic acid and others which are high in these plants.

\section{Conclusion}

The present study confirms that the corms, rhizomes and tubers can act as a good resource of fatty acid. However, their fatty acids may be beneficial to human beings and animals since plant fatty acids have become a major player in the alleviation of most human diseases. The findings of this study thus open us to new areas of research in the utilization of these plants in functional food production.

\section{References}

Alozie, Y., Akpanabiatu, M.I., Umoh, I.B., Eyong, E.U. and Alozie, G. (2009). Amino acid composition of Dioscorea dumentorum varieties. Pakistan Journal of Nutrition, 8(2), 103-105. https://doi.org/10.3923/ pjn.2009.103.105

Alozie, Y.E., Lawal, O.O., Umoh, I.B. and Akpanabiatu, M. I. (2010). Fatty acid composition of Dioscorea dumentorum (Px) varieties. African Journal of Food 
Agriculture Nutrition and Development, 10, 29562566. https://doi.org/10.4314/ajfand.v10i8.60884

Arinathan, V., Mohan, V.R., John De Britto, A. and Murugan, C. (2007). Wild edibles used by Palliyars of the Western Ghats, Tamil Nadu. Indian Journal of Traditional Knowledge, 6, 163-168.

Arinathan, V., Mohan, V.R. and Maruthupandian, A. (2009). Nutritional and antinutritional attributes of some under-utilized tubers. Tropical and Subtropical Agroecosystems, 10, 273-278.

Attia, R.S., Aman, M.E., El Tabey Shebata, A.M. and Hamza, M.A. (1996). Effect of ripening stage and technological treatments on the lipid composition, lipase and lipoxygenase activities of chick pea (Cicer arietinum L.). Food Chemistry, 56(2), 123-129. https://doi.org/10.1016/0308-8146(95)00135-2

Aurand, L.W., Woods, A.E. and Wells, M.R. (Eds.). (1987). In Food composition and analysis. New York, USA: Van Nostrand Reinhold Company. https://doi.org/10.1007/978-94-015-7398-6

Babu, L., Nambisan, B. and Sundaresan, S. (1990). Comparative evaluation of biochemical constituents of selected tuber crops. Journal of Root Crops, 16, 270-273.

Bhandari, M.R., Kasai, T. and Kawabata, J. (2003). Nutritional evaluation of wild yam (Dioscorea spp.) tubers of Nepal. Food Chemistry, 82(4), 619-623. https://doi.org/10.1016/S0308-8146(03)00019-0

Brown, A.J.P., Roberts, D.C.K. and Cherikoff, V. (1985). Fatty acids in indigenous Australian Foods. Proceedings of the Nutrition Society of Australia, 10, 209-212.

Ciacao, C.F. and D'Appolonia, B.L. (1978). Baking studies with Cassava and yam flour I. Biochemical composition of Cassava and yam flour. Cereal Chemistry, 55, 402-411.

Folch, J., Lees, M. and Solane-Stanly, G.M. (1957). A simple method for the isolation and purification of total lipids from animal tissues. Journal of Biology and Chemistry, 226(1), 497 - 506.

Kouassi, B., Diopoh, J., Lenoy, Y. and Fournet, B. (1988). Total amino acids and fatty acids composition of yam (Dioscorea) tubers and their evolution during storage. Journal of Science Food and Agriculture, 42(3), 273-285. https:// doi.org/10.1002/jsfa. 2740420310

Mohan, V.R. and Kalidass, C. (2010). Nutritional and antinutritional evaluation of some unconventional wild edible plants. Tropical and subtropical Agroecosystems, 12, 495- 506.

Muzac-Tucker, I., Asemota, H.N. and Ahmad, M.H. (1993). Biochemical composition and storage of
Jamaican yams (Dioscorea sp.). Journal of Science Food and Agriculture, 62(3), 219-224. https:// doi.org/10.1002/jsfa.2740620303

Metcalfe, L.D., Schemitz, A.A. and Pelka, J.R. (1966). Rapid preparation of fatty acid esters from lipids for gas chromatographic analysis. Analytical Chemistry, 38, 514 - 515. https://doi.org/10.1021/ac60235a044

Nair, D.B. and Nair, V.M. (1992). Nutritional studies in sweet potato. Journal of Root Crops, 18, 53- 57.

Opute, F.I. and Osagie, A.V. (1978). Fatty acid composition of total lipids from some tropical storage organs. Journal of Science Food and Agriculture, 29(11), 959-962. https:// doi.org/10.1002/jsfa.2740291110

Pugalenthi, M., Vadivel, V., Gurumoorthi, P. and Janardhanan, K. (2004). Comparative nutritional evaluation of little known legumes, Tamarindus indica, Erythrina indica and Sesbania bispinosa. Tropical and Subtropical Agroecosystems, 4, 107123.

Rajalakshmi, P. and Geervani, P. (1994). Nutritive value of the foods cultivated and consumed by the tribals of South India. Plant Foods for Human Nutrition, 46, 53-61. https://doi.org/10.1007/BF01088461

Shanthakumari, S., Mohan, V.R. and John De Britto, A. (2008). Nutritional evaluation and elimination of toxic principles in wild yam (Dioscorea spp.). Tropical and Subtropical Agroecosystems, 8, 313319.

Shajeela, P.S., Mohan, V.R., Louis Jesudass, L. and Tresina Soris, P. (2011). Nutritional and antinutritional evaluation of wild yam (Dioscorea spp.). Tropical and Subtropical Agroecosystems, 14, 723-730.

Shajeela, P., Tresina, P.S. and Mohan, V.R. (2013). Fatty acid composition of wild yam (Dioscorea spp.). Tropical and Subtropical Agroecosystems, 16, 35-38

Udensi, E.A., Oselebe, H.O. and Iweala, O.O. (2008). The investigation of chemical composition and functional properties of water yam (Dioscorea alata): Effect of varietal differences. Pakistan Journal of Nutrition, 7(2), 342-344. https:// doi.org/10.3923/pjn.2008.342.344

Ugwu, F.M. (2009). The potentials of roots and tubers as wearing food. Pakistan Journal of Nutrition, 8(10), 1701-1705. https://doi.org/10.3923/ pjn.2009.1701.1705

Vidyarthi, L.P. (1987). Role of forest in tribal life. In Sinha, S.P. (Ed.) Tribals and Forest, p. 323. Ranchi, India: Bihar Tribal Welfare Research Institute. 